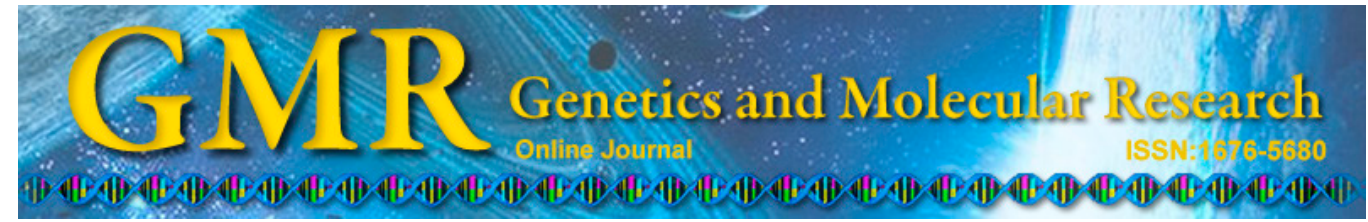

\title{
Assessment of the cytotoxic, genotoxic, and mutagenic potential of Acrocomia aculeata in rats
}

\author{
G.K. Traesel' ${ }^{1}$, L.H.A. Castro ${ }^{1}$, P.V.B. Silva ${ }^{2}$, R.M. Muzzi ${ }^{2}$, C.A.L. Kassuya ${ }^{1}$, \\ A.C. Arena ${ }^{1,3}$ and S.A. Oesterreich ${ }^{1}$ \\ ${ }^{1}$ Laboratório de Toxicologia, Faculdade de Ciência da Saúde, \\ Universidade Federal da Grande Dourados, Dourados, MG, Brasil \\ ${ }^{2}$ Faculdade de Ciências Exatas e Tecnologia, \\ Universidade Federal da Grande Dourados, Dourados, MG, Brasil \\ ${ }^{3}$ Departamento de Morfologia, Instituto de Biociências de Botucatu, \\ Universidade Estadual Paulista, Botucatu, SP, Brasil \\ Corresponding author: G.K. Traesel \\ E-mail: giselitraesel@gmail.com \\ Genet. Mol. Res. 14 (1): 585-596 (2015) \\ Received May 22, 2014 \\ Accepted September 27, 2014 \\ Published January 26, 2015 \\ DOI http://dx.doi.org/10.4238/2015.January.26.13
}

\begin{abstract}
Acrocomia aculeata (Jacq.) Lodd. ex Mart. is a plant species commonly used as a foodstuff and also for treating diseases, since it contains high concentrations of antioxidant compounds and monounsaturated fatty acids. Considering its ethnopharmacological relevance, the aim of the present study was to assess the cytotoxic, genotoxic, and mutagenic effects of an oil extracted from the pulp of $A$. aculeata (OPAC) in rats. In addition, a chromatographic characterization of the fatty acids present in OPAC was performed. Male and female Wistar rats were treated orally with $125,250,500,1000$, or $2000 \mathrm{mg} /$ $\mathrm{kg} /$ body weight OPAC. The effects of OPAC ingestion were determined by performing the comet assay and micronucleus test. The comet assay data demonstrated that OPAC did not increase the frequency or rate of
\end{abstract}


DNA damage in groups treated with any of the concentrations assessed compared to that in the negative control group. In the micronucleus test, the animals treated did not exhibit any cytotoxic or mutagenic changes in peripheral blood erythrocytes. The results demonstrated that OPAC did not exhibit cytotoxic, genotoxic, or mutagenic effects in Wistar rats, thereby increasing the evidence for the safety of oil extracted from this plant.

Key words: Bocaiúva; Comet assay; Micronucleus test; Oleic acid

\section{INTRODUCTION}

Medicinal plants and their derivatives have been extensively used as alternatives to allopathic drugs worldwide (Oliveira et al., 2011). However, despite the widespread use of these plant compounds, few studies have been conducted to determine their safety and efficacy (Reyes-García, 2010; de Melo et al., 2011).

Acrocomia aculeata (Jacq.) Lodd. ex Mart., popularly known as "bocaiúva" or "macaúba", is a plant that is widely distributed in the midwest region of Brazil (Lorenzi, 2006). Analysis of the fruit pulp of $A$. aculeata by high-performance liquid chromatography revealed the presence of high levels of antioxidants such as $\beta$-carotene (Ramos et al., 2008; Sanjinez-Argandoña and Chuba, 2011; Rocha et al., 2013), $\alpha$-tocopherol (Coimbra and Jorge, 2011), and monounsaturated fatty acids such as oleic acid (Amaral et al., 2011; Mariano et al., 2011). Antioxidants are important in the prevention of age-associated degenerative diseases (Barreiros et al., 2006; Gama and Sylos, 2007; Nagaraju and Lokesh, 2007). Oleic acid reduces the synthesis of low-density lipoprotein and increases the levels of highdensity lipoprotein cholesterol, which is associated with reduced risk for cardiovascular diseases (e.g., hypertension, stroke, and peripheral atherosclerosis), and antioxidant activity (Nagaraju and Lokesh, 2007).

While A. aculeata pulp can be used as food (Lorenzi, 2006; Ramos et al., 2008) and in the production of cosmetics (Silva, 2012), its use for disease prevention has recently increased (Silva, 2012). This medicinal plant has traditionally been used to treat respiratory diseases, and it also has laxative, analgesic, and restorative properties (Lorenzi, 2006). In addition, pharmacological studies have shown that it can reduce plasma glucose and total cholesterol levels (Silva, 2012). Although A. aculeata exhibits therapeutic properties that have increased its use, very few studies have been conducted to assess its toxicological effects. These toxicological assays are essential for the assessment and registration of new chemical compounds (Morita et al., 1997; Stange et al., 2009) by international agencies and government institutions.

In the present study, the comet assay and the micronucleus test were used to determine the toxicity of oil extracted from the pulp of $A$. aculeata (OPAC). The comet assay is a fast, simple, and sensitive method used to detect and quantify DNA breakage and it only requires a small number of suitable cells (McNamee et al., 2000). The micronucleus test is usually used to assess exposure to physical or chemical agents. A micronucleus test using the peripheral blood of rodents has been reported (Hayashi et al., 1990) as an alternative 
for this assay, which was previously standardized using bone marrow cells. It is therefore possible to obtain multiple blood samples from the same animal at different time-points and assess the effects of acute and chronic treatment using this modified technique (de Oliveira et al., 2012).

Considering the therapeutic potential of OPAC and the scarcity of information about its toxicity, the aim of the present study was to assess its cytotoxic, genotoxic, and mutagenic effects in rats by using the comet assay and the micronucleus test.

\section{MATERIAL AND METHODS}

\section{Botanical material}

Ripe A. aculeata fruits were collected $\left(22^{\circ} 13^{\prime} 18^{\prime \prime} \mathrm{S}\right.$ and $\left.54^{\circ} 48^{\prime} 23^{\prime \prime} \mathrm{W}\right)$ between June and September of 2012. The plant species were identified by Dr. L.S. Nogueira. A voucher specimen was deposited in the Herbarium of Universidade Federal da Grande Dourados (UFGD) under protocol No. 2169.

\section{Oil preparation}

The $A$. aculeata fruit were washed and peeled and the pulp was scarified. The pulp was then dried in a ventilated incubator and kept at $50^{\circ} \mathrm{C}$ for $2 \mathrm{~h}$. After drying, the material $(500 \mathrm{~g})$ was diluted in $1 \mathrm{~L}$ hexane. The solution was stored in the dark for 7 days. Finally, it was filtered and concentrated at $57^{\circ} \mathrm{C}$ in a rotary evaporator (Oetterer et al., 2006). The OPAC was stored in glass containers at $-4^{\circ} \mathrm{C}$ and protected from the light. Prior to usage, the oil was suspended in $2 \%$ Tween $^{\circledR} 80$ and diluted in saline solution to produce the dose required.

\section{Determination of the acid values}

In a sterile flask, $2 \mathrm{~g}$ OPAC was added to $25 \mathrm{~mL}$ ethyl ether/ethanol (2:1) and two drops of phenolphthalein. Titration was then performed with a standard solution of $0.1 \mathrm{~N}$ $\mathrm{NaOH}$. All analyses were conducted in triplicate and the results are reported as $\mathrm{mg}$ of $\mathrm{KOH} / \mathrm{g}$ OPAC (Silva, 2012).

\section{Transesterification}

OPAC (200 g) was weighed and mixed with $60 \mathrm{~mL}$ methanol and $2 \mathrm{~g} \mathrm{KOH}$. The mixture was stirred and heated to $60^{\circ} \mathrm{C}$. The reaction was followed using thin-layer chromatography. After OPAC was fully consumed, the solution was decanted for $1 \mathrm{~h}$ to separate the glycerin phase. The methanolic phase was treated with $10 \mathrm{~mL}$ distilled water plus $10 \%$ $\mathrm{NaCl}(10 \mathrm{~mL})$, dried with $\mathrm{MgSO}_{4}$, and finally filtered and concentrated in a rotary evaporator (Silva, 2012). 


\section{Characterization of methyl monoesters}

Gas chromatography (GC) was performed, followed by detection using mass spectrometry (DMS) or flame ionization detection (FID), to determine the chemical composition of the methyl fatty acid monoesters.

GC/DMS was performed using the Varian chromatograph model 431-GC210MS with a ZB-5 column ( $30 \mathrm{~cm} \times 0.25 \mathrm{~mm}$ ), using $99.99 \%$ helium as the carrier gas and a flow rate of $3.0 \mathrm{~mL} / \mathrm{min}$. Mass spectrometry was performed using the SCAN-m/z 40-700 ionization electron-impact mode, using the oven temperature of $50^{\circ} \mathrm{C}$ for $1 \mathrm{~min}, 5^{\circ} \mathrm{C}$ for $1 \mathrm{~min}, 248^{\circ} \mathrm{C}$ for $6 \mathrm{~min}$, with sample injection, mode split 50:1; sample volume, $0.1 \mu \mathrm{L}$; and fatty acid methyl ester standards. The chromatographic conditions for GC/FID were as follows: column, ZBWax (5\% phenyl 95\%, dimethylpolysiloxane); carrier gas, $99.99 \%$ helium; flow rate, $3.0 \mathrm{~mL} /$ min; temperature of detector, $250^{\circ} \mathrm{C}$; oven temperature, $50^{\circ} \mathrm{C}$ for $1 \mathrm{~min}, 5^{\circ} \mathrm{C}$ for $1 \mathrm{~min}, 248^{\circ} \mathrm{C}$ for 6 min; sample injection, mode split 50:1; sample volume, $0.1 \mu \mathrm{L}$; and fatty acid methyl ester standards.

Values were determined by comparing sample retention times and fragmentation profiles with those of fatty acid methyl ester standards analyzed under the same conditions. Quantification was performed by relating the peak area percentages to the mass percentage $(\%$ fatty acid $=$ peak area of each fatty acid x $100 /$ sum of all peak areas of fatty acids) (Silva, 2012).

\section{Animals}

Seventy Wistar rats (Rattus norvegicus) were used in the present study. Animals of both genders (35 male and 35 female), of a similar age (8-10 weeks old) and weight (200 g $\pm 20 \%$ ). The rats were provided by UFGD and maintained under controlled conditions at a temperature of $22 \pm 2^{\circ} \mathrm{C}, 40-60 \%$ humidity, and a 12/12-h dark-light cycle. The animals were kept in polypropylene cages, with ad libitum access to food and water.

The present study was approved by the Ethics Committee for Animal Experimentation of UFGD under protocol No. 028-2013. In order to reduce animal suffering, all procedures followed the standards of the Brazilian College of Animal Experimentation (COBEA, 2003).

\section{Experimental groups and dosages}

The OPAC dosages were based on our previous determination of the median lethal dose $\left(\mathrm{LD}_{50}\right)$, which was higher than $2000 \mathrm{mg} / \mathrm{kg}$ (Traesel, 2014). Five different dosages (2000, $1000,500,250$, and $125 \mathrm{mg} / \mathrm{kg}$ ) were tested. In addition, negative and positive control groups were treated intraperitoneally with saline solution plus $2 \%$ Tween $^{\circledR} 80$ and cyclophosphamide $(50 \mathrm{mg} / \mathrm{kg})$, respectively.

The animals were divided into seven experimental groups, with five males and five females per group. Five groups received the OPAC dosages listed above and the other two groups received negative and positive control treatments. OPAC was administered through oral gavage at a final volume of $2 \mathrm{~mL} /$ animal. 


\section{Micronucleus test}

These analyses were performed at $48 \mathrm{~h}$ after exposure (acute treatment) and $72 \mathrm{~h}$ after exposure (chronic treatment). At each time-point, blood samples were collected and blood smears were performed on glass slides. The slides were dried, fixed in methanol for 5 min, and stained with Giemsa (1:10 in phosphate buffer, pH 6.8) for 20 min. Finally, each slide was washed and kept in plastic boxes until the time of the microscopic analysis (Hayashi et al., 1990).

Each slide was analyzed and the presence of micronuclei was determined in 2000 polychromatic erythrocytes. This analysis revealed the micronucleated polychromatic erythrocytes (MNPCE) parameters (Hayashi et al., 1990). The ratio of polychromatic to normochromatic erythrocytes (PCE/NCE) was also calculated to assess the cytotoxic potential. In this case, 1000 erythrocytes were analyzed and immature (polychromatic) and mature (normochromatic) erythrocytes were identified (Hayashi et al., 1990).

\section{Comet assay}

These analyses were performed at $4 \mathrm{~h}$ after exposure (acute treatment) and at $24 \mathrm{~h}$ after exposure (chronic treatment). At each time-point, blood samples were collected and 40 $\mu \mathrm{L}$ was transferred to microtubes containing $120 \mu \mathrm{L}$ of low melting-point agarose $(1.5 \%)$ at $37^{\circ} \mathrm{C}$. The mixture was homogenized and transferred to slides pre-coated with $5 \%$ agarose (da Silva et al., 2010).

The slides were covered with cover slips and placed at $3^{\circ} \mathrm{C}$ for $20 \mathrm{~min}$. The cover slips were then removed and the slides were immersed in lysis solution $[89 \mathrm{~mL}$ stock lysis solution (2.5 M NaCl, $100 \mathrm{mM}$ EDTA, $10 \mathrm{mM}$ Tris, pH 10.0), $89 \mathrm{~mL}$ distilled water, and 1\% lauroylsarcosinate], $1 \mathrm{~mL}$ Triton X-100 (Sigma-Aldrich), and $10 \mathrm{~mL}$ dimethyl sulfoxide for 1 $\mathrm{h}$ at $3^{\circ} \mathrm{C}$ in the dark (da Silva et al., 2010).

In order to denature the DNA, the slides were placed in an electrophoresis chamber containing buffer solution at $\mathrm{pH}>13(300 \mathrm{mM} \mathrm{NaOH}$ and $1 \mathrm{mM}$ EDTA, prepared from a stock solution of $10 \mathrm{~N} \mathrm{NaOH}$ and $200 \mathrm{mM}$ EDTA, pH 10.0) at $3^{\circ} \mathrm{C}$ for $20 \mathrm{~min}$ in the dark. Electrophoresis was performed at $25 \mathrm{~V}$ and $300 \mathrm{~mA}$. The slides were then neutralized using $0.4 \mathrm{M}$ Tris- $\mathrm{HCl}$ at $\mathrm{pH} 7.5$ for three cycles of $5 \mathrm{~min}$ each, dried, fixed with $100 \%$ ethanol for 10 $\mathrm{min}$, and stored for later analysis. Finally, the slides were stained with ethidium bromide (20 $\mathrm{mg} / \mathrm{mL}$ ) and covered with a cover slip. All material was analyzed by fluorescence microscopy (40X magnification), equipped with an excitation filter $(420-490 \mathrm{~nm})$ and a barrier filter (520 nm) (da Silva et al., 2010).

Each slide was identified and analyzed in a blind test. The cells (200 per animal; 100 for each time-point) were analyzed randomly. The comet findings were classified as follows: class 0 (no damage); class 1 (comet tail shorter than the diameter of the nucleoid); class 2 (comet tail once or twice the diameter of the nucleoid); and class 3 (comet tail greater than twice the size of the nucleoid). Comets with a turbid aspect or a head that was too small were excluded from the analyses, as they could represent dead cells (da Silva et al., 2010).

From these data, damage index (DI) and damage frequency (DF) were calculated. 
The DI was calculated by multiplying the number of damaged cells by the value assigned to that damage. Therefore, this value ranged from 0 (no damage: 100 cells $\times 0$ ) to 300 (maximum damage: 100 cells $\mathrm{x} 3$ ). DF was calculated by adding the number of damaged cells (class 1, 2 or 3 ) and ranged from 0 (no damage) to 100 (maximum damage) (da Silva et al., 2010).

\section{Statistical analysis}

The results are reported as means \pm standard error of the mean. Data were analyzed by one-way analysis of variance (ANOVA) and the significance of any differences between the groups was determined by the Tukey post-hoc test. The significance level was set at $5 \%$.

\section{RESULTS}

The results of the present study demonstrated efficient solvent extraction of OPAC with a satisfactory yield (38\%) and a low level of acidity $(0.48 \mathrm{mg} \mathrm{KOH} / \mathrm{g}$ OPAC and $0.65 \mathrm{mg}$ $\mathrm{KOH} / \mathrm{g}$ of monoester). The material obtained was of good quality and was stable enough to be transesterified and characterized.

Comparison of the sample GC/DMS peaks with the respective fatty acid (methyl ester) standards produced the following results, reported as a percentage of the peak area \pm standard error: lauric acid $(0.184 \pm 0.019)$; myristic acid $(0.243 \pm 0.086)$; palmitoleic acid $(2.016$ $\pm 0.203)$; palmitic acid (28.626 \pm 4.352$)$; linoleic acid $(2.605 \pm 0.341)$; oleic acid (61.092 \pm 2.731); stearic acid (2.978 \pm 0.631$)$; and arachidonic acid (1.087 \pm 0.194$)$. As the peaks of the main compounds present in OPAC overlapped in the GC/DMS analysis, GC/FID analysis was performed to obtain a better separation of these compounds.

The GC/FID percentage data of the area obtained from the OPAC peaks were as follows: lauric acid (0.250); myristic acid (0.070); palmitoleic acid (2.031); palmitic acid (20.587); linoleic acid (2.050); oleic acid (71.305); stearic acid (2.614); linoleic acid (0.311); and arachidonic acid (0.154). The results of the chromatographic analyses demonstrated the presence of unsaturated linoleic fatty acid, the peak shift of the saturated stearic fatty acid, and the non-overlapping of the peak of the unsaturated oleic fatty acid.

The results of the rat micronucleus tests are displayed in Table 1. These results indicated that groups treated with OPAC exhibited similar averages (at both time-points and for both parameters analyzed) to those observed in the negative control group, and that these differed from those observed in the positive control group $(\mathrm{P}<0.001)$. This showed that exposure to OPAC did not alter the number of MNPCEs.

Table 2 shows the effects of the five concentrations of OPAC on the migration of DNA from peripheral blood leukocytes of Wistar rats, $4 \mathrm{~h}$ and $24 \mathrm{~h}$ after administration. These results showed that the groups treated did not exhibit changes in the DI and DF of DNA, when compared with the negative control group. Conversely, these parameters were significantly different $(\mathrm{P}<0.001)$ to those observed in the positive control group. 


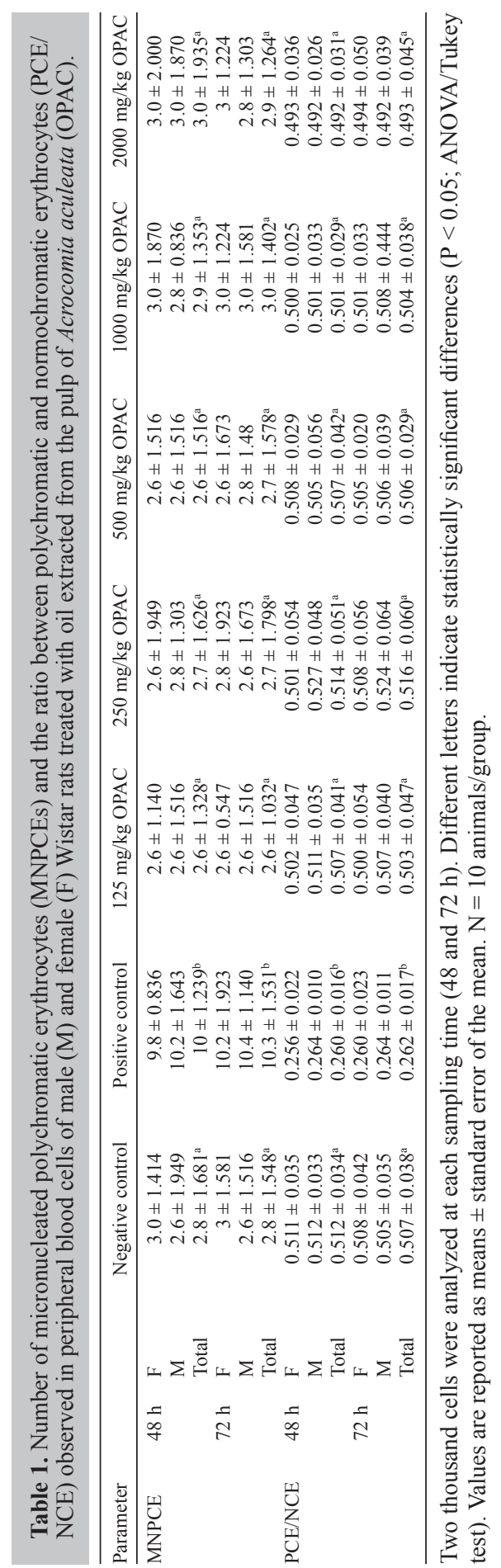


G.K. Traesel et al.

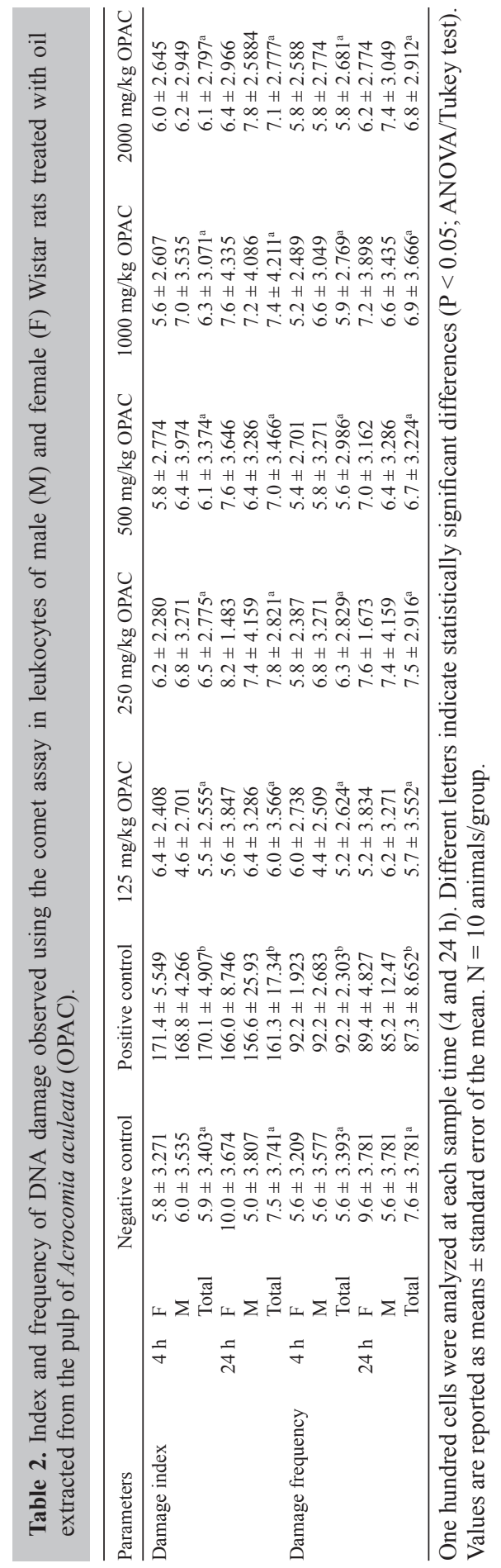




\section{DISCUSSION}

According to previous studies (Hiane et al., 2005; Bergouignan et al., 2009), OPAC exhibited higher levels of monounsaturated fatty acids than other vegetable oils such as olive, soy, corn, cottonseed, sunflower, and flaxseed oils. For instance, a previous study reported that OPAC contained $69.07 \%$ oleic acid (Amaral et al., 2011). These data were similar to the findings of the present study, where a predominance of oleic acid was detected by GC/MSD and GC/FID.

Recently, the number of studies of plant extracts and their biological activities in humans and animals has increased (Farsi et al., 2013). However, the pharmacological studies reported have not been sufficient to validate the effects of these plant compounds on whole organisms (Reyes-García, 2010). Therefore, further studies of their toxicity are essential to establish a safe dosage (de Melo et al., 2011). The genotoxicity of several plants that are commonly used for their therapeutic properties has already been determined, including those of "lobeira" (Solanum lycocarpum), "barbatimão" (Stryphnodendron adstringens), "espinheira-santa" (Maytenus ilicifolia), "goiaba vermelha" (Psidium guajava), and "sucupira" (Bowdichia virgilioides) (Fonseca and Pereira, 2004). However, A. aculeata, a medicinal plant with active molecules important for disease prevention (Silva, 2012), requires further investigation in this area.

The micronucleus test is an assay that is commonly used in genetic toxicology to determine the mutagenicity of a chemical compound (Morita et al., 1997). In recent years, this test has been utilized worldwide, both in vivo (using rodent and fish cells) and in vitro (using a range of cell types). Previous studies have demonstrated that plant extracts can induce the formation of a micronucleus during cell division through clastogenic (resulting in chromosome fragmentation caused by breaks) or aneugenic (resulting in the loss of whole chromosomes during cell division) actions (Salamone et al., 1980). During the telophase, these fragments or whole chromosomes are added to smaller nuclei known as "micronuclei", that are separate from the main nucleus (Kirsch-Volders et al., 2002).

In the present study, the results of the micronucleus test revealed a similar number of MNPCEs in all five test groups, and in the negative control group. These results indicated that OPAC did not exhibit clastogenic or aneugenic effects either 48 or $72 \mathrm{~h}$ after oral administration to rats. In contrast, the positive control $(50 \mathrm{mg} / \mathrm{kg}$ intraperitoneal cyclophosphamide) significantly increased the number of micronucleated cells $(\mathrm{P}<0.001)$, as previously reported (de Oliveira et al., 2012).

In addition to the analysis of mutagenic effects, the micronucleus test also enabled the determination of cytotoxic effects. The PCE/NCE was used as an indicator of the toxic effects of OPAC. Drugs that reduce the production of polychromatic erythrocytes are considered to be cytotoxic (Gollapudi and McFadden, 1995). The PCE/NCE ratios in the test groups were similar to those found in the negative control group, indicating that OPAC did not affect erythrocyte proliferation and was not considered cytotoxic to this cell type.

Studies of the different types of DNA damage have provided important information about aging, genetics, and cancer (Singh et al., 1991). The alkaline version ( $\mathrm{pH} \geq 13.0)$ of the comet assay has been widely used to assess the genotoxic potential of compounds in vivo (Lee and Steinert, 2003). This is a sensitive, fast, and affordable test, which can detect breaks in one or both DNA strands, as well as anomalous DNA-DNA and DNA-protein connections. Analysis of the cellular material 4 and $24 \mathrm{~h}$ after treatment with the test substance can identify damage occurring before (4 h) and after (24 h) DNA repair (Tice et al., 2000).

The results of the present study revealed a significant increase in damage of DNA 
from peripheral blood leukocytes of Wistar rats in all of the test groups. With regard to DF and DI, the treated groups exhibited results similar to those exhibited by the negative control group, and different results from those found in the positive control group $(\mathrm{P}<0.001)$. These results are in agreement with the data obtained in the micronucleus test, confirming that OPAC did not exhibit genotoxicity.

DNA strand breaks may occur directly due to damage caused by exposure to reactive oxygen species (ROS), or indirectly due to the cleavage of DNA during base excision repair (El-Khamisy and Caldecott, 2006). DNA damage caused by oxidation is considered to be the type of damage that is most relevant to normal cellular metabolism. It has been estimated that approximately $2 \times 10^{4}$ oxidative DNA lesions occur in the human genome daily (Ames and Shigenaga, 1992). Evidence suggests that cumulative DNA damage caused by ROS contributes to several clinical conditions, including cancer (Palyvoda et al., 2003). For this reason, a number of researchers have suggested that antioxidant substances can exhibit anti-carcinogenic properties (Katiyar et al., 1994; Antunes and Takahashi, 1999).

A previous study analyzed the acute and sub-acute toxicities of OPAC were assessed by hemato-biochemical and histopathological analyses of vital and reproductive organs. The results indicated a $\mathrm{LD}_{50}$ of more than $2000 \mathrm{mg} / \mathrm{kg}$ and the absence of any clinical signs that could be associated with toxic effects (Traesel et al., 2014).

The absence of toxicity is consistent with the results of the present study in terms of the cytotoxicity, genotoxicity, and mutagenicity of OPAC in Wistar rats.

In conclusion, these data provide important information about a species (A. aculeata) with great economic and medical importance. However, further studies should be performed to assess other aspects of toxicity, such as long-term toxicity ( 90 days to 1 year).

\section{Conflicts of interest}

The authors declare no conflict of interest.

\section{REFERENCES}

Amaral FP, Broetto F, Batistella CB and Jorge SMA (2011). Extração e caracterização qualitativa do óleo da polpa e amêndoas de frutos de Macaúba [Acrocomia aculeata (Jacq) Lodd. ex Mart] coletadanaregião de Botucatu - SP. Rev. Ener. Agric. 26: 12-20.

Ames BN and Shigenaga MK (1992). Oxidants are a major contributor to aging. Ann. N. Y. Acad. Sci. 663: 85-96.

Antunes LMG and Takahashi CS (1999). Olive oil protects against chromosomal aberrations induced by doxorubicin in Wistar rat bone marrow cells. Gen. Mol. Biol. 22: 225-227.

Barreiros ALBS, David JP and David JM (2006). Estresse oxidativo: relação entre espécies reativas de oxigênio e a defesa do organismo. Quim. Nova 29: 113-123.

Bergouignan A, Momken I, Schoeller DA, Simon C, et al. (2009). Metabolic fate of saturated and monounsaturated dietary fats: the Mediterranean diet revisited from epidemiological evidence to cellular mechanisms. Prog. Lipid. Res. 48: 128-147.

Coimbra MC and Jorge N (2011). Proximate composition of guariroba (Syagrus oleracea), jerivá (Syagrus romanzoffiana) and macaúba (Acrocomia aculeata) palm fruits. Food Res. Int. 44: 2139-2142.

Colégio Brasileiro de Experimentação Animal (COBEA) (2003). Princípios Éticos Na Experimentação Animal. São Paulo.

da Silva CJ, dos Santos JE and Satie TC (2010). An evaluation of the genotoxic and cytotoxic effects of the anti-obesity drugs sibutramine and fenproporex. Hum. Exp. Toxicol. 29: 187-197.

de Melo JG, Santos AG, de Amorim EL, do Nascimento SC, et al. (2011). Medicinal plants used as antitumor agents in Brazil: an ethnobotanical approach. Evid. Based. Complement. Alternat. Med. 2011: 365359.

de Oliveira PR, Bechara GH, Denardi SE, Oliveira RJ, et al. (2012). Genotoxic and mutagenic effects of fipronil on mice. 
Exp. Toxicol. Pathol. 64: 569-573.

el-Khamisy SF and Caldecott KW (2006). TDP1-dependent DNA single-strand break repair and neurodegeneration. Mutagenesis 21: 219-224.

Farsi E, Shafaei A, Hor SY, Ahamed MB, et al. (2013). Genotoxicity and acute and subchronic toxicity studies of a standardized methanolic extract of Ficus deltoidea leaves. Clinics 68: 865-875.

Fonseca CA and Pereira DG (2004). Aplicação da genetic toxicological em planta com atividade medicinal. Infarma 16: 77-88.

Gama JJT and Sylos CM (2007). Effect of thermal pasteurization and concentration on carotenoid composition of Brazilian Valencia Orange juice. Food Chem. 100: 1688-1690.

Gollapudi BB and McFadden LG (1995). Sample size for the estimation of polychromatic to normochromatic erythrocyte ratio in the bone marrow micronucleus test. Mutat. Res. 347: 97-99.

Hayashi M, Morita T, Kodama Y, Sofuni T, et al. (1990). The micronucleus assay with mouse peripheral blood reticulocytes using acridine orange-coated slides. Mutat. Res. 245: 245-249.

Hiane PA, Filho MMR, Ramos MIL and Macedo MLR (2005). Bocaiúva, Acrocomia aculeta (Jacq.) Lodd., pulp and kernel oils: characterization and fatty acid composition. Braz. J. Food Techn. 8: 256-259.

Katiyar SK, Agarwal R and Mukhtar H (1994). Inhibition of spontaneous and photo-enhanced lipid peroxidation in mouse epidermal microsomes by epicatechin derivatives from green tea. Cancer Lett. 79: 61-66.

Kirsch-Volders M, Vanhauwaert A, De BM and Decordier I (2002). Importance of detecting numerical versus structural chromosome aberrations. Mutat. Res. 504: 137-148.

Lee RF and Steinert S (2003). Use of the single cell gel electrophoresis/comet assay for detecting DNA damage in aquatic (marine and freshwater) animals. Mutat. Res. 544: 43-64.

Lorenzi GMAC (2006). Acrocomia Aculeata (Jacq.) Lodd. ex Mart. - Arecaceae: Bases para o Extrativismo Sustentável. Doctoral thesis. Universidade Federal do Paraná, Curitiba.

Mariano RGB, Da Silva CM, Couri S and Nogueira RI (2011). Partition of free fatty acids in deacidification of macaúba pulp oil by liquid-liquid extraction using ethanol/water as solvent. Defectand Diffusion Forum 312: 554-559.

McNamee JP, McLean JR, Ferrarotto CL and Bellier PV (2000). Comet assay: rapid processing of multiple samples. Mutat. Res. 466: 63-69.

Morita T, Asano N, Awogi T, Sasaki YF, et al. (1997). Evaluation of the rodent micronucleus assay in the screening of IARC carcinogens (groups 1, 2A and 2B) the summary report of the 6th collaborative study by CSGMT/JEMS MMS. Collaborative Study of the Micronucleus Group Test. Mammalian Mutagenicity Study Group. Mutat. Res. 389: 3-122.

Nagaraju A and Lokesh BR (2007). Interesterified coconut oil blends with ground nut oil or live oil exhibit greater hypocholesterolemic effects compared with their respective physical blends in rats. Nutr. Res. 27: 580-586.

Oetterer M, Regitando-D'Arce MAB and Spoto MHF (2006). Fundamentos de Ciência e Tecnologia de Alimentos. 1st edn. Ed. Manole, Barueri.

Oliveira AKM, Oliveira NA, Resende UM and Martins PF (2011). Ethnobotany and traditional medicine of the inhabitants of the Pantanal Negro sub-region and the raizeiros of Miranda and Aquidauna, Mato Grosso do Sul, Brazil. Braz. J. Bio. 71: 283-289.

Palyvoda O, Polanska J, Wygoda A and Rzeszowska-Wolny J (2003). DNA damage and repair in lymphocytes of normal individuals and cancer patients: studies by the comet assay and micronucleus tests. Acta Biochim. Pol. 50: 181-190.

Ramos MIL, Ramos Filho MM, Hiane PA and Neto JAB (2008). Qualidade nutricional da polpa da bocaiúva Acrocomia aculeata (Jacq.) Lodd. Sci. Tecnol. Alim. 28: 90-94.

Reyes-García V (2010). The relevance of traditional knowledge systems for ethnopharmacological research: theoretical and methodological contributions. J. Ethnobiol. Ethnomed. 6: 32.

Rocha MS, Figueiredo RW, Araújo MA and Moreira-Araújo RS (2013). Physical and chemical characterization and antioxidant activity (in vitro) of fruit of the Piaui savanna. Rev. Bras. Frutic. 35: 4.

Salamone M, Heddle J, Stuart E and Katz M (1980). Towards an improved micronucleus test: studies on 3 model agents, mitomycin C, cyclophosphamide and dimethylbenzanthracene. Mutat. Res. 74: 347-356.

Sanjinez-Argandoña EJ and Chuba CAM (2011). Biometrical, physical and chemical characterization of bocaiuva (Acrocomia aculeata (Jacq.) Lodd. ex Mart) Palm fruits. Rev. Bras. Frutic. 33: 3.

Silva PVBS (2012). Caracterização Química e avaliação do Potencialantidiabético e Citotóxico de Oleo Extraído de Acrocomia aculeata (macaúba). Master's thesis. Universidade Federal da Grande Dourados, Dourados.

Singh NP, Tice RR, Stephens RE and Schneider EL (1991). A microgel electrophoresis technique for the direct quantitation of DNA damage and repair in individual fibroblasts cultured on microscope slides. Mutat. Res. 252: 289-296.

Stange VS, Gomes TDUH, Andrade MA and Batitucci MCP (2009). Avaliação do efeito mutagênico do extrato hidroalcoólico bruto, por meio de bioensaios in vivo e prospecção fitoquímica de Cecropia glaziovii Sneth (embaúba). 
Braz. J. Pharm. 19: 637-642.

Tice RR, Agurell E, Anderson D, Burlinson B, et al. (2000). Single cell gel/comet assay: guidelines for in vitro and in vivo genetic toxicology testing. Environ. Mol. Mutagen. 35: 206-221.

Traesel GK, Souza JC, Barros AL, Souza MA, et al. (2014). Acute and subacute (28 days) oral toxicity assessment of the oil extracted from Acrocomia aculeata pulp in rats. Food Chem. Toxicol. 74: 320-325. 